\title{
RECOMMENDER SYSTEM DENGAN KOMBINASI APRIORI DAN CONTENT-BASED FILTERING PADA APLIKASI PEMESANAN PRODUK
}

\author{
Lukas Tommy $^{1}$, Chandra Kirana ${ }^{2)}$, Vivi Lindawati ${ }^{3)}$ \\ ${ }^{123}$ Teknik Informatika, STMIK Atma Luhur \\ 123 Jl. Jend. Sudirman, Selindung Baru, Pangkalpinang \\ Email:'lukastommy@atmaluhur.ac.id, ${ }^{2}$ chandra.kirana@atmaluhur.ac.id, ${ }^{3}$ 1411500093@mahasiswa.atmaluhur.ac.id
}

\begin{abstract}
Abstrak
Sistem penjualan dan pemasaran produk sembako di Toko Menkong sampai sekarang dilakukan secara konvensional. Masalah ini menyebabkan kurang optimalnya omset yang diperoleh toko akibat dari jumlah transaksi produk yang tidak terlalu sering pada setiap harinya. Permasalahan tersebut dapat ditanggulangi dengan berbagai cara, satu di antaranya dengan membangun aplikasi berbasis Android untuk memesan produk. Tingginya mobilitas, popularitas, open source dan penggunaannya yang mudah menjadi bahan pertimbangan dalam pemilihan Android daripada sistem operasi dan platform yang lain. Aplikasi yang dibangun akan dilengkapi recommender system atau lebih dikenal sebagai sistem rekomendasi dengan memanfaatkan algoritma Apriori serta metode content-based filtering. Kemampuan untuk menyarankan item baru ke pengguna dengan berdasarkan kesamaan karakteristik dari item yang sebelumnya disukai pengguna merupakan alasan pemilihan metode content-based filtering. Faktor simpel, efisien, dan mampu menangani banyak data menjadi alasan pemilihan algoritma Apriori daripada algoritma lain. Model prototyping, metode berorientasi objek dan UML (Unified Modelling Language) merupakan model, metode, dan tools pengembangan perangkat lunak yang dimanfaatkan di paper ini. Pencarian dan pemesanan produk oleh pelanggan menjadi lebih mudah dengan aplikasi yang dibangun, sehingga kecepatan dan efisiensi transaksi meningkat. Recommender system aplikasi cukup akurat dalam menyarankan produk menurut kategori produk di keranjang, hobi pelanggan, dan pola pembelian, yaitu sebesar 73,33\%.
\end{abstract}

Kata Kunci: Recommender System, Apriori, ContentBased Filtering, M-Commerce, Android

\section{Pendahuluan}

Pertumbuhan teknologi informasi, salah satunya internet yang semakin pesat di abad ke-21 mempengaruhi peradaban dan gaya hidup bermasyarakat. Kegiatan komunikasi, interaksi, serta transaksi dalam jarak jauh secara cepat, mudah, dan berbiaya murah menjadi mungkin berkat kehadiran internet [1].

Ponsel cerdas (smartphone), terutama yang berbasis Android pada saat ini bukanlah merupakan barang mewah, dimana hampir seluruh lapisan masyarakat memilikinya. Smartphone ini digunakan oleh masyarakat sebagai media hiburan, komunikasi, berbisnis, bahkan untuk kegiatan jual beli barang antar para penggunanya melalui aplikasi tertentu. Android sendiri merupakan Sistem Operasi (SO) yang dikembangkan dengan berlandaskan kernel Linux yang bersifat open source dan paling banyak diimplementasikan pada perangkat cerdas di dunia [2].

Usaha perniagaan bisa diartikan sebagai salah satu jenis usaha dengan aktivitas pokok membeli lalu menyimpan komoditas di gudang, setelah itu menjualnya lagi tanpa diproses sebelumnya [3]. Supermarket, agen tunggal, pengecer, toko serba ada, toko kelontong, pusat perbelanjaan, plaza, atau pusat barang grosir adalah usaha yang dikategorikan ke dalam usaha perniagaan.

Satu dari berbagai tempat usaha perniagaan yang ada di Jebus, Kecamatan Parittiga, Kabupaten Bangka Barat adalah Toko Menkong, dimana ia menjual produk seperti suku cadang alat berat dan sembako. Sistem penjualan dan pemasaran produk sembako di Toko Menkong sampai sekarang dilakukan secara konvensional. Hal ini berarti pelanggan harus datang langsung ke toko untuk mencari dan membeli produk yang diinginkan, sehingga tidak praktis dalam hal waktu, biaya transportasi, dan tenaga yang dikeluarkan. Masalah ini menyebabkan kurang optimalnya omset yang diperoleh toko akibat dari jumlah transaksi produk yang tidak terlalu sering pada setiap harinya sekaligus faktor eksternal seperti persaingan bisnis.

Permasalahan tersebut dapat ditanggulangi dengan berbagai cara, satu di antaranya adalah dengan membangun aplikasi berbasis Android untuk memesan produk. Tingginya mobilitas, popularitas, open source dan penggunaannya yang mudah menjadi bahan pertimbangan dalam pemilihan Android daripada sistem operasi dan platform yang lain [4]. Konsumen nantinya bisa memesan produk sembako di Toko Menkong dengan menggunakan aplikasi yang dibangun, yang setelahnya produk tersebut akan dikirim oleh pegawai toko ke tempat konsumen.

Aplikasi yang dibangun akan dilengkapi recommender system atau lebih dikenal sebagai sistem rekomendasi dengan memanfaatkan algoritma Apriori serta metode content-based filtering. Kemampuan untuk menyarankan item baru ke pengguna dengan berdasarkan kesamaan karakteristik dari item yang sebelumnya disukai pengguna merupakan alasan pemilihan metode contentbased filtering [5]. Faktor simpel, efisien, dan mampu menangani banyak data menjadi alasan pemilihan 
algoritma Apriori daripada algoritma lain. Selain itu, polapola kombinasi item dapat dianalisa oleh algoritma ini [5].

Terdapat beberapa paper yang berhubungan dengan recommender system dan telah dipunlikasi sebelum paper ini dikerjakan. Penggunaan metode item collaborative filtering pada perancangan sistem rekomendasi pakaian distro oleh Susanto [6]. Produk yang mungkin disukai konsumen bisa diprediksi berdasarkan histori produk seperti apa yang paling laris. Santoso dan Kusumaningrum [7] mengimplementasikan algoritma naive bayes dan metode content-based filtering pada recommender system untuk jual beli online. Produk yang disarankan cocok dengan kesukaan pengguna berkat penerapan 2 metode ini di recommender system, sehingga dapat dikatakan sukses.

Sistem rekomendasi dengan algoritma Apriori dan content based filtering yang dilaksanakan oleh Badriyah dkk. [5] dimana perpaduan 2 pendekatan ini bisa menganalisa pola-pola kombinasi item. Dengan berlandaskan transaksi jual beli yang dulunya dilakukan konsumen di e-commerce, sistem dapat memberikan saran produk. Produk yang disarankan bagi masing-masing pengguna anggota yang aktif dan terdaftar bisa diperlihatkan. Di tiap-tiap detail produk yang ditampilkan, bisa disarankan produk berbeda menurut persentase kemunculan milik produk berbeda dari pengguna yang saat itu menunjukkan detail produk. Penetapan nilai confidence dan support merupakan nilai yang berpengaruh pada banyaknya saran produk yang ditunjukkan. Semakin kecil nilai confidence dan support yang ditetapkan, semakin banyak rekomendasi yang ditunjukkan. Semakin besar nilai confidence dan support yang ditetapkan, semakin sedikit rekomendasi yang ditunjukkan.

Sarkaleh et al. [8] membangun recommender system untuk memandu wisata dengan platform web. Metode collaborative filtering dan personalization, serta algoritma $K$-means clustering digunakan dalam paper tersebut. Informasi jasa seperti hiburan, penginapan, biro perjalanan, toko-toko, serta restoran bisa disiapkan oleh aplikasi yang dibangun. Yanti dkk. [9] melakukan publikasi mengenai rekomendasi hardware game pada Toko Pelita Abadi Games dengan penerapan collaborative filtering. Angka mean absolut error yang dihasilkan pada eksperimen dengan metode ini termasuk akurat, yaitu sebesar 0,739 .

Badriyah dkk. [10] menciptakan recommender system hybrid yang menerapkan pendekatan collaborative filtering dan content-based filtering pada e-commerce. Ia nantinya mengkalkulasi kesamaan profil pengguna dan gambaran produk. Hasil tag yang diciptakan secara otomatis dicampur dengan profil pengguna oleh sistem yang dibangun untuk memperoleh saran yang berkaitan. Pada hasil pengujian, ditemukan bahwa saran mempunyai kesamaan dengan gambaran produk dan kesukaan profil pengguna dengan rata-rata nilai keakuratan sebesar 67,5\% dan nilai recall sebesar $71,47 \%$. Penelitian ini meamnfaatkan metode Text Mining TF-IDF (term frequency-inverse document frequency) dalam menciptakan tag secara otomatis sesuai gambaran produk.
Armando [11] menerapkan sistem rekomendasi yang menggunakan content-based filtering dan algoritma Apriori pada e-commerce. Konsumen bisa dengan cepat mendapatkan item yang diinginkan dengan memanfaatkan feature recommender system pada e-commerce.

Diharapkan dengan kehadiran aplikasi yang akan dibangun bisa membuat pangsa pasar Toko Menkong menjadi lebih luas. Selain itu juga diharapkan dapat mempercepat, mempermudah, dan menjadikan transaksi produk lebih efisien sekaligus efektif, sehingga dapat memaksimalkan omset toko.

\section{Metode}

\subsection{Model Pengembangan Perangkat Lunak}

Pada penelitian ini, model prototyping dipilih sebagai model pengembangan perangkat lunak, yaitu satu dari sekian metode siklus hidup sistem yang berlandaskan pada model konsep bergerak guna membangun model ke bentuk sistem final [12]. Fase-fase pada model prototyping dapat dilihat pada Gambar 1.

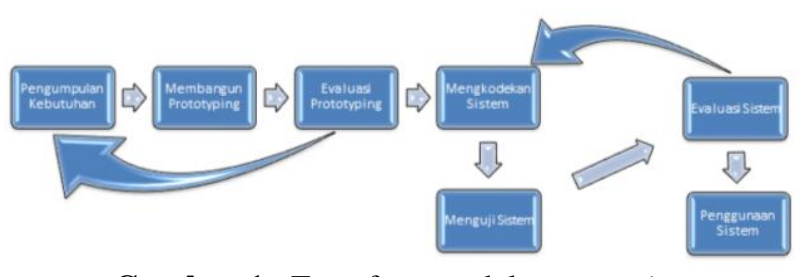

Gambar 1. Fase-fase model prototyping.

A. Pengumpulan Kebutuhan

Sistem penjualan sekaligus dan pemasaran produk di Toko Menkong dilakukan secara konvensional, dimana pembeli harus datang langsung ke toko untuk mencari dan membeli produk yang ada. Hal ini menyebabkan toko tidak mampu bersaing dengan minimarket sekitar dimana memiliki fasilitas dan modal yang lebih baik, mengakibatkan tidak maksimalnya pendapatan yang diperoleh. Salah satu upaya agar Toko Menkong mampu bersaing dengan pesaingnya adalah dengan membuat aplikasi pemesanan produk berbasis Android. Aplikasi ini nantinya dapat digunakan untuk mencari dan memesan produk tanpa harus datang ke Toko Menkong, kemudian produk tersebut akan diantarkan oleh kurir ke lokasi pelanggan.

\section{B. Membangun Prototyping}

Pada fase ini akan dilaksanakan desain tampilan layout sekaligus fitur-fitur pada aplikasi. Di fase ini juga akan didesain pseudocode dari recommender system yang nanti akan diterapkan di aplikasi.

\section{Evaluasi Prototyping}

Purwa-rupa (prototipe) dari fase terdahulu kemudian dievaluasi oleh para stakeholders Toko Menkong (pengelola, karyawan, dan pelanggan) dalam hal antarmuka sekaligus fungsi. Developer aplikasi akan mengumpulkan kebutuhan lagi dengan feedback dari para stakeholders jika purwarupa belum disetujui. 
D. Mengkodekan Sistem

Pada fase ini, rancangan layout dan fungsi diterapkan menjadi aplikasi dengan fungsi yang berjalan seutuhnya. Proses desain tampilan dan coding menggunakan Integrated Development Environment (IDE) Android Studio dengan bahasa pemrograman Java. Recommender system yang akan dibangun menggunakan algoritma apriori (berdasarkan skema pembelian produk oleh pelanggan pada umumnya) dan metode content-based filtering (berdasarkan hobi yang dipilih pelanggan saat mendaftar akun dan ciri-ciri produk di keranjang pelanggan).

\section{E. Menguji Sistem}

Blackbox testing dipilih sebagai model pengujian dalam menguji fungsi-fungsi (input dan output) yang dimiliki aplikasi [13]. Selain itu juga akan dilakukan simulasi untuk mengukur kemampuan recommender system dalam merekomendasikan produk berdasarkan suatu kasus .

\section{F. Evaluasi Sistem}

Aplikasi yang telah lolos pengujian blackbox dan simulasi akan diuji sekali lagi oleh para stakeholders apakah telah memenuhi kebutuhan sebelum dipublikasikan. Developer akan mengulangi fase mengkodekan sistem berbekal feedback yang diberikan seandainya aplikasi belum sesuai keinginan para stakeholders.

\section{G. Penggunaan Sistem}

Aplikasi yang sudah dievaluasi dan dinyatakan lulus oleh para stakeholders kemudian di-hosting pada suatu penyedia layanan hosting. Android Package File (APK) aplikasi selanjutnya diunggah pada Google Play Store agar dapat diunduh oleh calon pembeli untuk mencari dan memesan produk. Promosi APK ini dapat dilakukan menggunakan sosial media, mulut ke mulut ataupun dicetak pada spanduk toko.

\subsection{Metode Pelaksanaan Penelitian}

Metode berorientasi objek yang digambarkan menggunakan Unified Modeling Languange (UML) dipilih sebagai metode pengembangan sistem dalam membangun aplikasi ini. Menurut Nugroho [14], pendekatan berorientasi objek yaitu sebuah upaya membangun sistem informasi dan software berlandaskan abstraksi objek - objek yang terdapat pada kehidupan sehari-hari. Model berorientasi objek memudahkan software untuk dimodifikasi dan lebih fleksibel oleh karena itu tepat untuk diterapkan di software yang nantinya dibangun. Salah satu contoh bahasa pemrograman yang menunjang Object-Oriented Programming (OOP) adalah Java yang dipakai di Android Studio.

\subsection{Tools Pengembangan Sistem}

UML merupakan tools pengembangan sistem yang dipakai dalam membangun aplikasi ini. Menurut Nugroho [15], UML adalah bahasa baku untuk memodelkan proses bisnis dan software yang biasanya dimanfaatkan pada pendekatan berorientasi objek. Diagram sequence, diagram class, diagram activity, dan diagram use case merupakan diagram-diagram UML yang dipakai pada pembangunan aplikasi ini.

\subsection{Algoritma Apriori}

Algoritma Apriori adalah salah satu algoritma untuk menjalankan pencarian frequent itemset dengan association rules. Algoritma Apriori memakai pendekatan level-wise search, dimana $k$-itemset dipakai untuk mendapatkan $(k+1)$-itemset. Proses ini dilaksanakan sampai tidak ada lagi kombinasi yang dapat dibentuk [16]. Berdasarkan persamaan-persamaan mengenai support dan confidence yang ada di [16], serta ulasan di [17], didapatkan persamaan (1), (2), dan (3).

Persamaan (1) digunakan untuk menghitung nilai support untuk sebuah item.

$$
\operatorname{Support}(A)=\frac{\text { Jumlah Transaksi mengandung } A}{\text { Total Transaksi }}
$$

Persamaan (2) digunakan untuk menghitung nilai support dari 2 item

$$
\begin{aligned}
& \text { Support }(A, B) \\
& =\frac{\text { Jumlah Transaksi mengandung } A \text { dan } B}{\text { Total Transaksi }}
\end{aligned}
$$

Persamaan (3) digunakan untuk menghitung nilai confidence dari rule $A \rightarrow B$

$$
\begin{aligned}
& \text { confidence }(A \rightarrow B) \\
& =\frac{\text { Jumlah Transaksi mengandung } A \text { dan } B}{\text { Jumlah Transaksi mengandung } A}
\end{aligned}
$$

Algoritma Apriori sering dimanfaatkan di market basket (data transaksi). Sebagai contoh suatu supermarket mempunyai market basket, pemilik supermarket bisa memahami pola belanja seorang pelanggan dengan keberadaan algoritma Apriori. Jika seorang pelanggan belanja produk, misalkan roti, dan susu, dia memiliki peluang $50 \%$ belanja produk mentega. Skema seperti ini sangat berarti dengan keberadaan data transaksi sampai sekarang [18].

Cara kerja algoritma Apriori adalah sebagai berikut:

a. Tetapkan support minimum

b. Perulangan 1 : kalkulasikan item-item dari support (transaksi yang mengandung semua item) dengan memindai basis data bagi 1-itemset, sesudah 1itemset diperoleh, dari 1-itemset apakah di atas support minium, jika sudah mencukupi support minimum, 1-itemset itu nantinya menjadi pola frequent tinggi.

c. Perulangan 2 : demi memperoleh 2-itemset, perlu dilaksanakan gabungan dari k-itemset terdahulu, setelah itu pindai basis data kembali guna mengkalkulasi item-item yang mengandung support. itemset yang mencukupi support minimum nantinya dipilih menjadi skema frequent tinggi dari calon

d. Tentukan angka k-itemset dari support yang sudah mencukupi support minimum dari k-itemset 
e. Kerjakan proses bagi perulangan berikutnya sampai tidak ditemukan lagi k-itemset yang mencukupi support minimum.

\subsection{Metode Content-based Filtering}

Rekomendasi produk menurut hasil uraian persamaan produk yang sudah ditaksir pemakainya adalah konsep dari content-based filtering [19]. Profil pemakai diwujudkan oleh content-based filtering menurut karakteristik perwujudan sebuah produk. Misalnya karakteristik perwujudan sebuah naskah yaitu ucapan yang ada di naskah itu. Faktor yang menentukan profil pemakai ini lalu diberikan angka bobot menurut suatu parameter. Hasil rekomendasi adalah faktor yang memiliki cosine similarity paling tinggi.

Tahap-tahapan dari content-based filtering adalah:

a. Berlandaskan sebuah vector unsur pembuatnya, sebuah benda dipisah-pisah.

b. Berlandaskan bobot vector unsur pembuat sebuah benda, sistem nantinya menciptakan profil pemakai. Penciptaan profil pemakai dilaksanakan memanfaatkan algoritma Term Frequency-Invers Document Frequency (TF-IDF). Jumlah term pada sebuah naskah merupakan pengertian $\mathrm{TF}$, sementara itu nilai IDF dapat dihitung memakai persamaan (4):

$$
i d f_{i}=\log \left(\frac{n}{d f_{i}}\right)
$$

$d f$ adalah jumlah naskah yang mempunyai term $i$, sedangkan $n$ adalah jumlah seluruh naskah

c. Berlandaskan profil pemakai itu, sistem kemudian menduga evaluasi gemar atau tidak digemarinya sebuah benda berlandaskan uraian keserupaan profil pemakai dengan vector unsur pembuat benda. Seandainya sistem menduga bahwa benda itu bakal digemari oleh pemakai, lalu benda itu nantinya diusulkan ke pemakai.

\section{Hasil dan Analisis}

\subsection{Analisa Kebutuhan}

Kebutuhan dari sistem yang nantinya dibangun didefinisikan melalui proses analisa kebutuhan. Kebutuhan fungsionil, kebutuhan non-fungsionil, dan kebutuhan pemakai adalah pembagian dari analisa kebutuhan. Hanya kebutuhan fungsionil saja yang akan dijelaskan di paper ini dengan mempertimbangkan jumlah halaman.

\section{A. Analisa Kebutuhan Fungsionil}

Aplikasi pemesanan produk yang akan dibangun memiliki kebutuhan-kebutuhan fungsional layaknya di bawah ini:

a. Terdapat aplikasi web yang dibangun untuk admin, dimana dengan menggunakan aplikasi ini seorang admin dapat menambah, melihat, mengubah, ataupun menghapus produk pada basis data, melakukan verifikasi pembayaran, sekaligus log out. Admin harus terlebih dahulu login sebelum dapat menggunakan fungsi-fungsi tersebut.

b. Terdapat aplikasi Android yang dibangun untuk pelanggan. Dengan memanfaatkan aplikasi ini, pelanggan dapat mendaftar akun, login, melihat-lihat produk toko (dan penyaringan), dan melihat detail produk. Pelanggan hanya bisa menambahkan produk ke keranjang, mengecek dan menata keranjang, memesan produk, melihat history transaksi, melihat detail transaksi, melihat dan mengganti profil, dan memperoleh saran produk jika sebelumnya pelanggan tersebut sudah pernah mendaftar dan berhasil login.

\section{B. Diagram Use Case}

Hubungan yang berlangsung di antara system dan actor yang ada diuraikan dengan diagram use case. Diagram use case aplikasi web untuk admin diperlihatkan pada Gambar 2, sedangkan diagram use case aplikasi Android untuk pelanggan diperlihatkan pada Gambar 3:

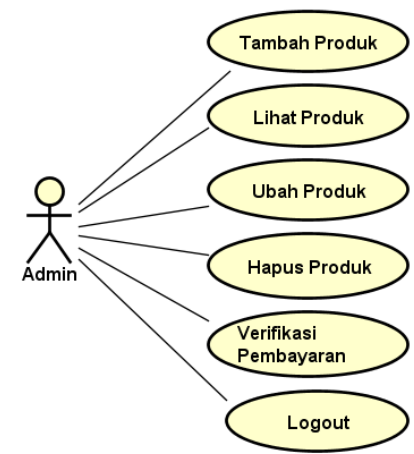

Gambar 2. Diagram use case aplikasi admin.

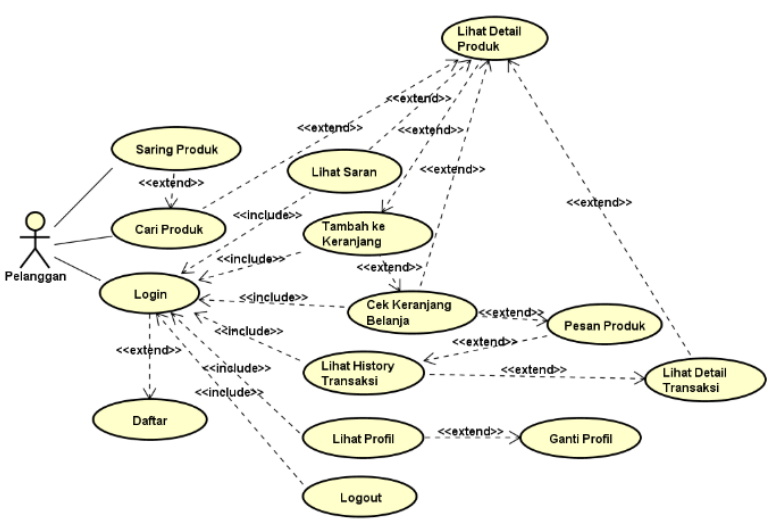

Gambar 3. Diagram use case aplikasi pelanggan.

\subsection{Desain Sistem}

Desain yang diciptakan untuk mengembangkan aplikasi pemesanan produk, yakni representasi kelakuan aplikasi menggunakan diagram sequence dan diagram activity, desain database menggunakan diagram class. Demikian juga metode content-based filtering dan algoritma Apriori didesain menggunakan pseudocode dan setelah itu diimplementasikan di recommender system aplikasi.
A. Diagram Sequence
Diagram sequence mendeskripsikan arus fungsi di use case dan menceritakan rangkaian hubungan objek yang 
dikomposisi pada rangkaian periode. Tiga dari berbagai diagram sequence pada pembangunan aplikasi Android pemesanan produk yaitu:

1) Diagram Sequence Pesan Produk

Pelanggan yang sudah login dan berada di halaman cek keranjang mengetuk tombol "BAYAR". Setelah itu sistem membaca data produk yang ada di keranjang pelanggan, kemudian menambahkan transaksi itu ke database. Apabila terjadi kesalahan, ditampilkanlah pesan kesalahan itu, jika tidak, keranjang pelanggan akan dikosongkan dan halaman history transaksi ditampilkan. Diagram sequence pesan produk adalah seperti yang diperlihatkan Gambar 4.

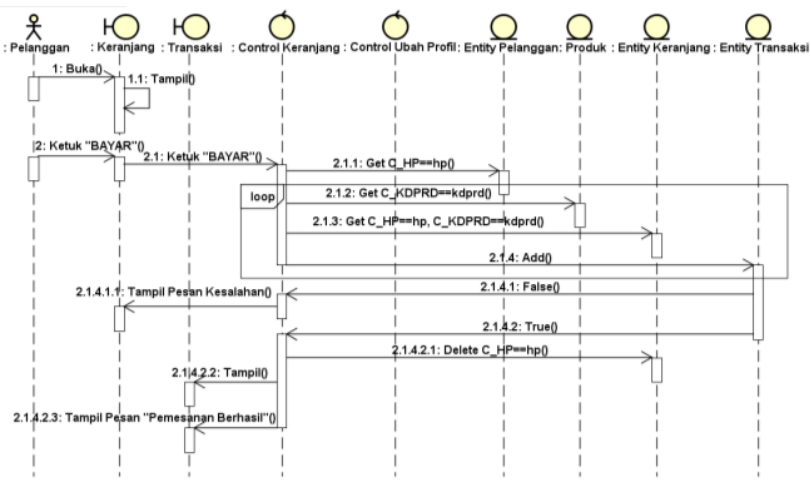

Gambar 4. Diagram sequence pesan produk.

\section{2) Diagram Sequence Cari Produk}

Pelanggan membuka aplikasi pemesanan produk yang dibangun, kemudian aplikasi akan menampilkan halaman splash screen selama 3 detik. Setelah 3 detik berlalu, sistem akan membaca semua produk yang ada di database, lalu menampilkannya di halaman beranda. Diagram sequence cari produk adalah seperti yang diperlihatkan Gambar 5.

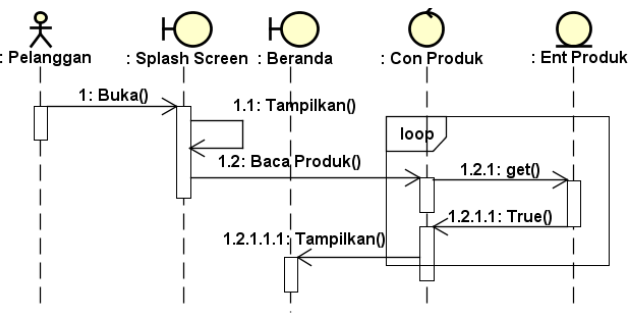

Gambar 5. Diagram sequence cari produk.

\section{3) Diagram Sequence Lihat Saran}

Pelanggan yang sudah login mengetuk "Rekomendasi" pada halaman drawer navigasi. Setelah itu sistem menginisialiasi skor, lalu mengkalkulasikan skor yang didapat setiap produk yang tersedia di etalase berdasarkan beberapa pertimbangan. Pertimbangan ini antara lain hobi pelanggan, kategori produk yang ada di keranjang, berikut kuantitas dari produk itu dan pola pembelian pelanggan secara umum yang belanja di toko. Berdasarkan skor itu, akan dipilih produk yang direkomendasikan. Diagram sequence lihat saran adalah seperti yang diperlihatkan Gambar 6.

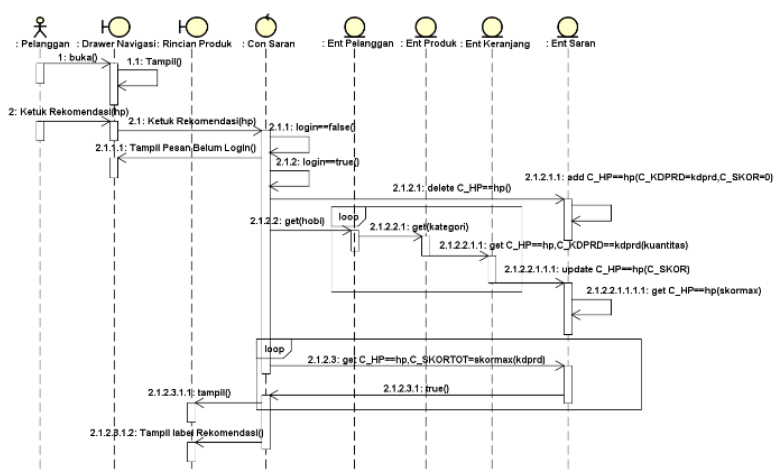

Gambar 6. Diagram sequence lihat saran.

B. Diagram Activity

Beberapa arus fungsi dari sistem yang dibangun dideskripsikan dengan diagram activity. Beberapa diagram activity pada pembangunan aplikasi Android pemesanan produk yaitu:

1) Diagram Activity Pesan Produk

Diagram activity pesan produk adalah seperti yang diperlihatkan Gambar 7.

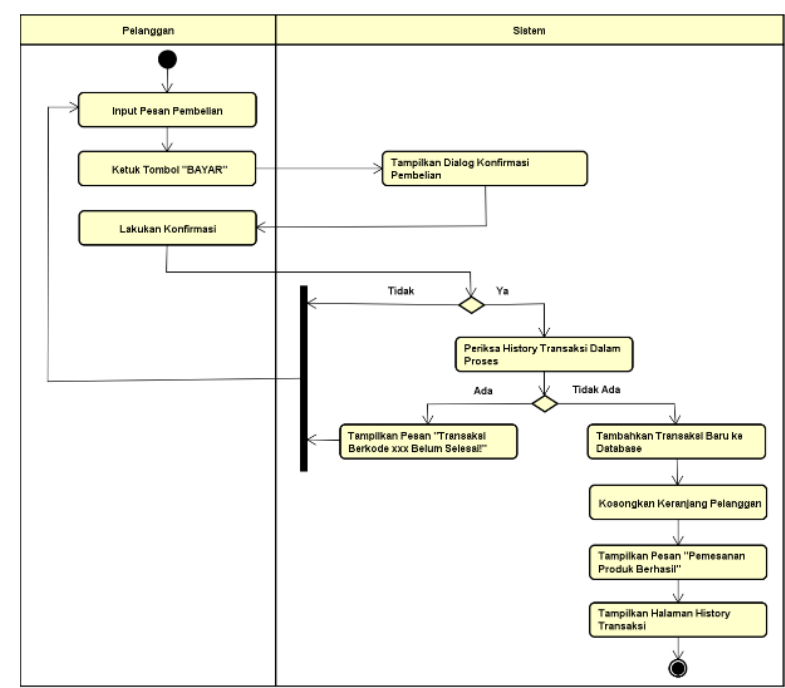

Gambar 7. Diagram activity pesan produk.

2) Diagram Activity Cari Produk

Diagram activity cari produk adalah seperti yang diperlihatkan Gambar 8.

3) Diagram Activity Lihat Saran

Diagram activity lihat saran adalah seperti yang diperlihatkan Gambar 9. 


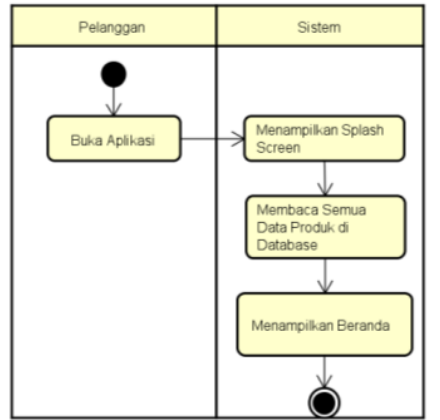

Gambar 8. Diagram activity cari produk.

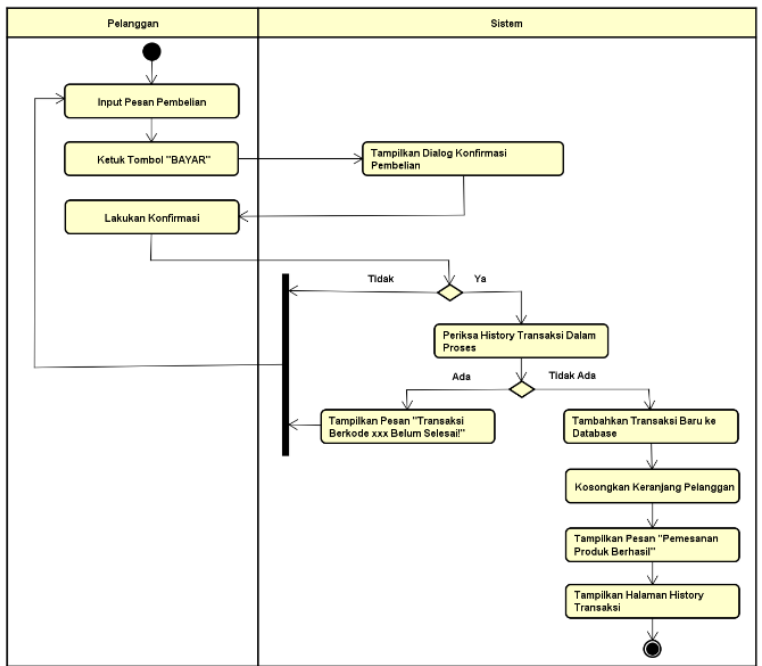

Gambar 9. Diagram activity lihat saran.

\section{Diagram Class}

Relasi di antara kelas dalam sistem yang tersusun atas kelas, atribut, dan metode dideskripsikan menggunakan diagram class. Semua visibilitas atribut kelas yang ada bersifat private (nilainya tidak bisa diakses secara langsung), sedangkan metode bersifat public. Diagram class aplikasi adalah seperti yang diperlihatkan Gambar 10.

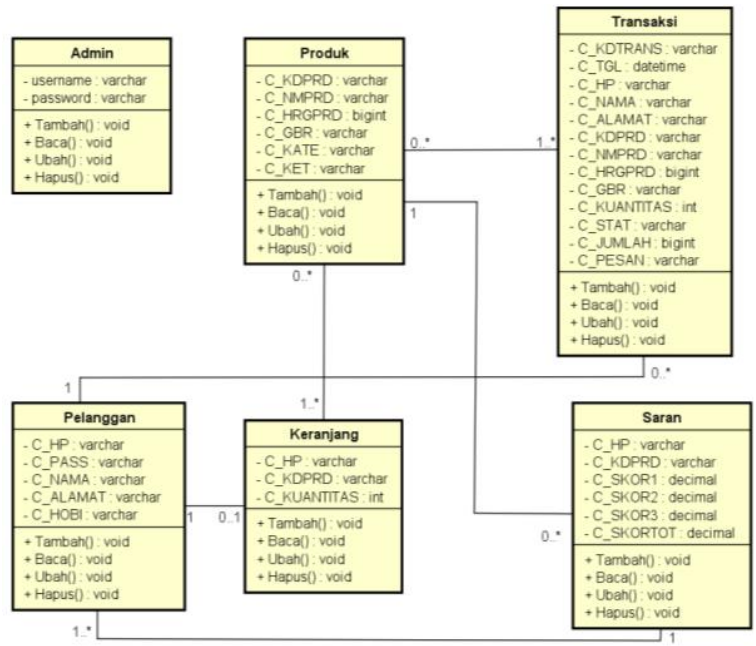

Gambar 10. Diagram class aplikasi.

D. Desain Algoritma

Desain algoritma di paper ini dicontohkan ke wujud pseudocode, yakni penulisan algoritma yang memakai susunan bahasa pemrograman yang simpel. Pseudocode beberapa algoritma yang dipakai pada recommender system yang akan dibuat adalah sebagai berikut:

1) Pemberian Skor Awal

Saat pelanggan yang sudah login mengetuk navigasi rekomendasi di halaman drawer navigasi pertama kali, seluruh skor untuk semua produk yang ada di database untuk pelanggan tersebut akan diberi nilai 0 (nol). Pseudocode pemberian skor awal adalah seperti yang diperlihatkan Gambar 11

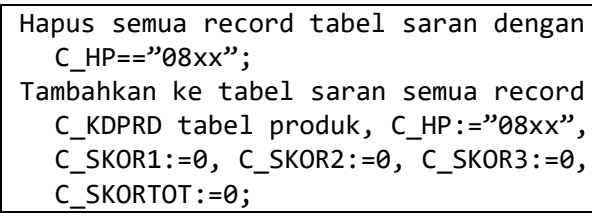

Gambar 11. Pseudocode pemberian skor awal.

\section{2) Kalkulasi Skor Menurut Hobi Pelanggan}

Pelanggan yang mempunyai suatu hobi biasanya condong terhadap memesan produk berkategori yang cocok dengan hobinya. Sebagai contoh, Budi yang gemar makan condong memesan produk dengan kategori makanan ringan. Pseudocode dari fase kalkulasi skor menurut hobi pelanggan (skor 1) yang nantinya menjadi masukan pada metode content-based filtering adalah seperti pada Gambar 12

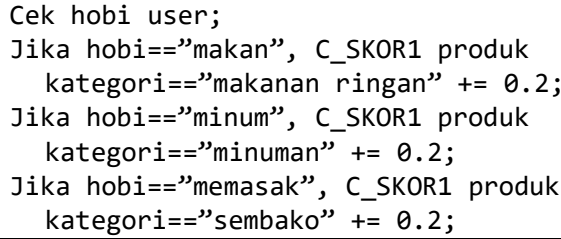

Gambar 12. Pseudocode kalkulasi skor menurut hobi

3) Kalkulasi Skor Menurut Kategori Produk di Keranjang

Pelanggan yang mempunyai sebuah produk berkategori tertentu $(\mathrm{X})$ di keranjangnya, condong memesan produk berkategori sama dengan produk itu. Misalkan Budi mempunyai 1 produk makanan ringan di keranjangnya. Dia nantinya condong untuk menambahkan produk makanan lain ke keranjangnya. Apabila telah ada cukup banyak produk makanan ringan di keranjang, maka pelanggan itu akan berhenti menambahkan produk makanan ringan ke keranjang. Pseudocode dari fase kalkulasi skor menurut kategori produk di keranjang (skor 2), yang akan menjadi input untuk metode content-based filtering adalah seperti yang diperlihatkan Gambar 13.

4) Kalkulasi Skor Menurut Skema Belanja Pelanggan pada Umumnya

Umumnya pelanggan yang memesan 1 atau lebih produk makanan ringan akan memesan minimal 1 produk minuman juga. Probabilitas pelanggan dalam memesan lebih banyak produk makanan ringan akan terus menurun apabila ada berbagai produk makanan ringan di 
keranjangnya. Selain itu, satu orang pelanggan berpeluang besar memesan 1 minuman saja (membeli untuk dirinya sendiri) jika dia juga memesan makanan ringan pada saat itu.

Algoritma Apriori sejatinya hanya dapat bekerja terhadap pelanggan yang sebelumnya sudah pernah berbelanja dan histori belanjanya tercatat di database. Pemanfaatan skema belanja pelanggan pada umumnya membuat algoritma Apriori dapat bekerja bahkan untuk pelanggan yang baru pertama belanja di toko tersebut dengan menggunakan asumsi yang berlaku umum di toko sembako. Pseudocode dari fase kalkulasi skor menurut skema belanja pelanggan pada umumnya (skor 3), yang akan menjadi input untuk algoritma Apriori adalah seperti yang ditunjukkan Gambar 14.

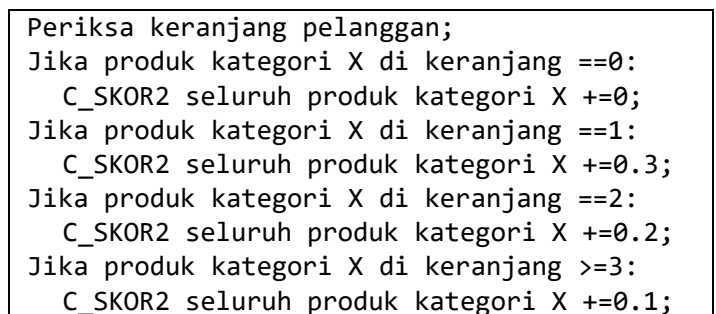

Gambar 13. Pseudocode kalkulasi skor menurut kategori produk di keranjang.

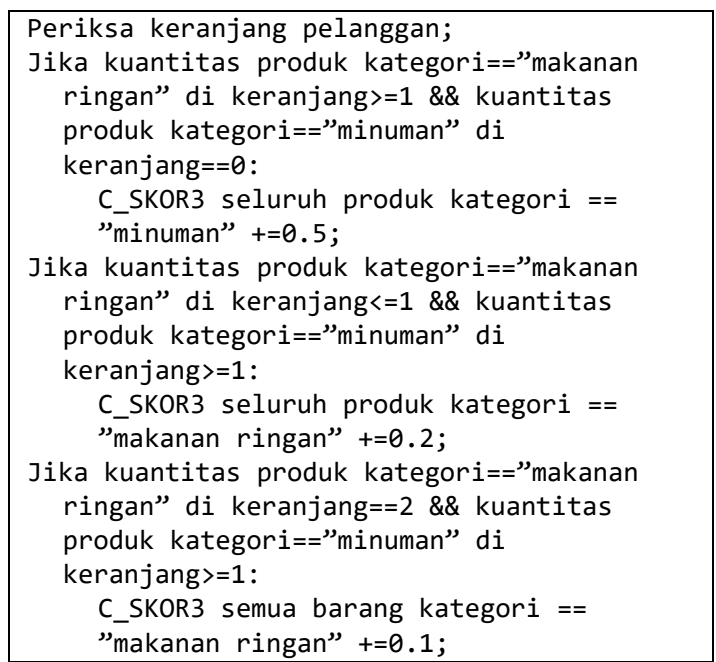

Gambar 14. Pseudocode kalkulasi skor menurut skema belanja pelanggan pada umumnya.

5) Kalkulasi Skor Total dan Saran Produk

Skor total merupakan penjumlah dari skor 1, skor 2 dan skor 3 bagi produk tersebut, atau dengan kata lain dianggap adalah perpaduan algoritma Apriori dan metode content-based filtering. Skor total produk yang telah terdapat di keranjang tetap 0, dengan asumsi pelanggan tak akan memerlukan rekomendasi produk yang telah ada di keranjangnya. Selain itu halaman detail dari produk itu sudah pernah dikunjungi sebelumnya, dimana pelanggan cukup mengetuk "BELI SEKARANG" untuk menambahkan produk yang sama itu ke keranjang. Selain itu, hal ini dilaksanakan guna memprioritaskan produk lain yang belum terdapat dalam keranjang untuk disarankan aplikasi. Skor maksimum merupakan skor total bernilai paling tinggi di antara produk yang terdapat di tabel saran. Apabila ada lebih dari 1 produk dengan skor total yang sama dengan skor maksimum, maka sebuah dari produk-produk tersebut nantinya dipilih secara acak oleh aplikasi guna disarankan ke pelanggan. Pseudocode dari fase kalkulasi skor total dan fase pemilihan produk yang disarankan adalah seperti yang ditunjukkan Gambar 15 .

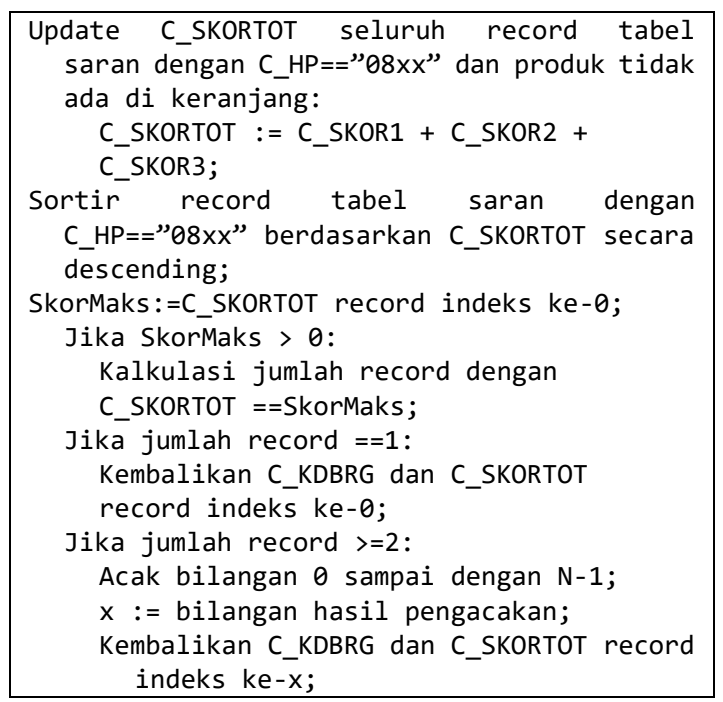

Gambar 15. Pseudocode kalkulasi skor total dan saran produk.

\subsection{Implementasi Sistem}

Implementasi sistem yang sudah dibangun pada fase desain sistem guna dioperasikan akan dilaksanakan di fase implementasi.

A. Tampilan Layar

Pada paper ini hanya beberapa dari seluruh tampilan layar aplikasi yang akan ditampilkan.

1) Tampilan Layar Beranda

Tampilan layar beranda dari aplikasi yang dibangun dapat dilihat pada Gambar 16.

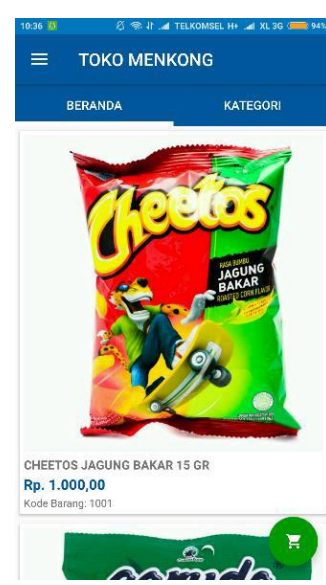

Gambar 16. Tampilan layar beranda.

2) Tampilan Layar Keranjang

Tampilan layar keranjang dari aplikasi yang dibangun 
dapat dilihat pada Gambar 17.

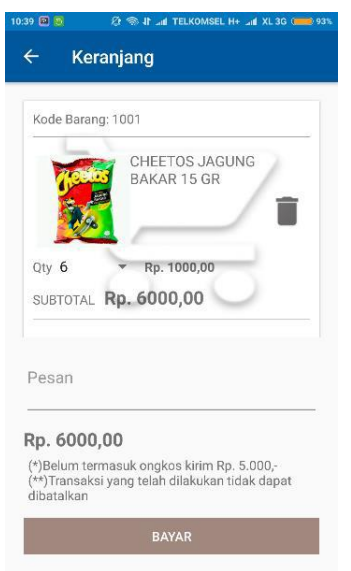

Gambar 17. Tampilan layar keranjang.

3) Tampilan Layar Detail Produk yang Disarankan Tampilan layar detail produk yang disarankan dari aplikasi yang dibangun dapat dilihat pada Gambar 18 .

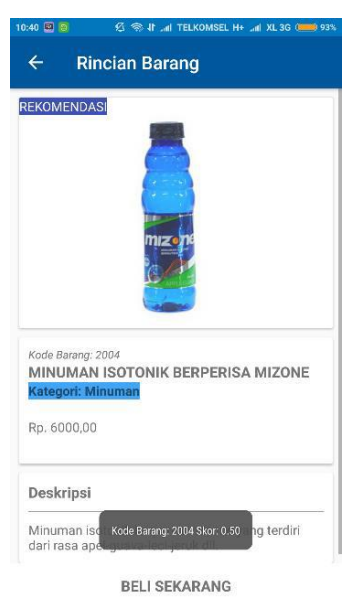

Gambar 18. Tampilan layar detail produk yang disarankan.

4) Tampilan Layar Navigasi Drawer Tampilan layar navigasi drawer dari aplikasi yang dibangun dapat dilihat pada Gambar 19.

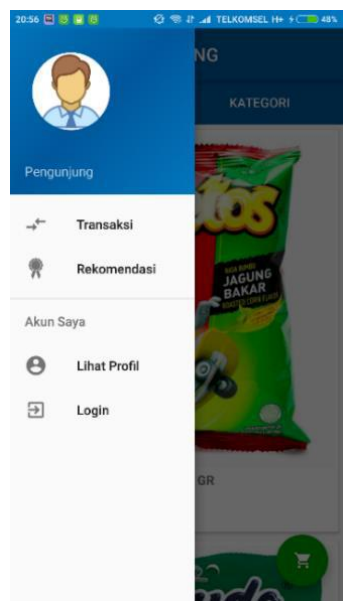

Gambar 19. Tampilan layar navigasi drawer.

\section{5) Tampilan Layar Login}

Tampilan layar login dari aplikasi yang dibangun dapat dilihat pada Gambar 20.

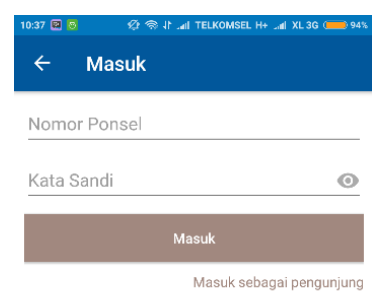

Gambar 20. Tampilan layar login.

6) Tampilan Layar Daftar

Tampilan layar daftar dari aplikasi yang dibangun dapat dilihat pada Gambar 21.

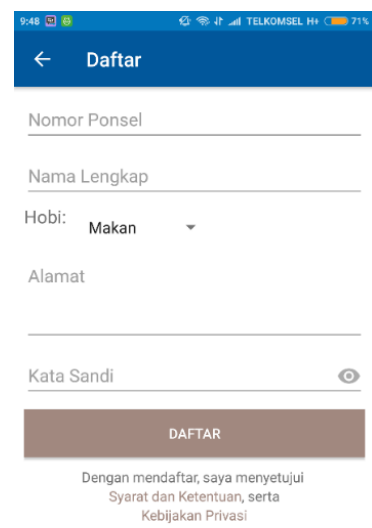

Gambar 21. Tampilan layar daftar.

7) Tampilan Layar History Transaksi

Tampilan layar history transaksi dari aplikasi yang dibangun dapat dilihat pada Gambar 22.

8) Tampilan Layar Detail Transaksi

Tampilan layar detail transaksi dari aplikasi yang dibangun dapat dilihat pada Gambar 23.

9) Tampilan Layar Tambah ke Keranjang Tampilan layar tambah ke keranjang transaksi dari aplikasi yang dibangun dapat dilihat pada Gambar 24.

10) Tampilan Layar Lihat Profil Tampilan layar lihat profil dari aplikasi yang dibangun dapat dilihat pada Gambar 25. 


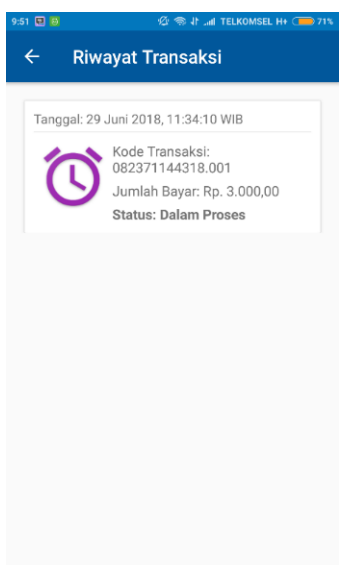

Gambar 22. Tampilan layar riwayat transaksi.

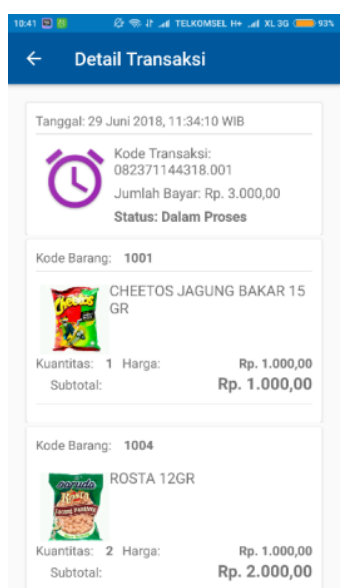

Gambar 23. Tampilan layar detail transaksi.

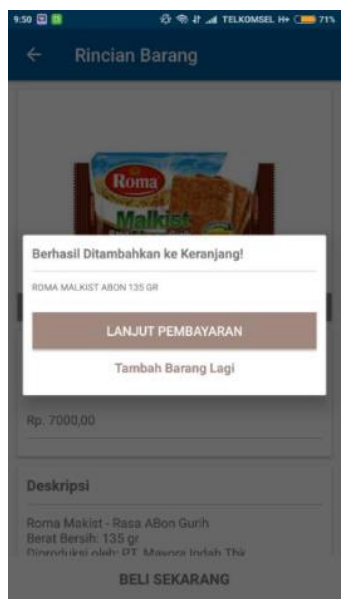

Gambar 24. Tampilan layar tambah ke keranjang.

B. Pengujian

Pada paper ini, nantinya diadakan black box testing untuk segi fungsionil dari aplikasi yang dibangun sekaligus eksperimen recommender system dalam menyarankan produk yang mungkin disukai oleh pelanggan.

\section{1) Black Box Testing}

Tabel 7 merupakan keluaran black box testing yang sudah dilaksanakan untuk aplikasi yang dibangun.

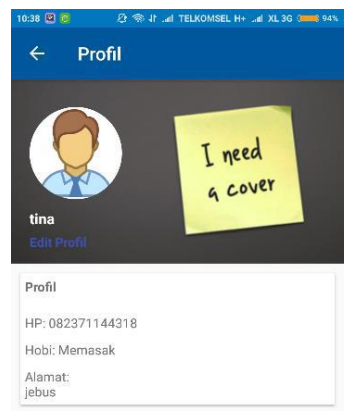

Gambar 25. Tampilan layar lihat profil.

Tabel 1. Keluaran Black Box Testing

\begin{tabular}{|c|c|}
\hline No & Pengujian \\
\hline 1 & $\begin{array}{l}\text { Tap ikon launcher } \\
\text { aplikasi Toko } \\
\text { Menkong yang } \\
\text { sudah dipasang } \\
\text { pada widget ponsel } \\
\text { Android }\end{array}$ \\
\hline 2 & $\begin{array}{l}\text { Menunggu } 3 \text { detik } \\
\text { di halaman splash } \\
\text { screen }\end{array}$ \\
\hline 3 & $\begin{array}{l}\text { Tap salah satu } \\
\text { kategori di halaman } \\
\text { kategori }\end{array}$ \\
\hline
\end{tabular}

Menunjukkan

OK

halaman beranda

Menunjukkan

OK

halaman beranda

dengan produk

yang ditampilkan

berkategori sama

dengan kategori

yang di-tap

$4 \quad$ Tap sebuah produk

Menunjukkan

di halaman beranda

halaman detail

produk yang di-tap

$5 \quad$ Pelanggan yang sudah login mengtap navigasi

Menunjukkan

halaman detail

produk sekaligus

rekomendasi di

halaman drawer

navigasi

label rekomendasi

dan kalimat yang

mengandung kode

produk dan

skornya

6 Pelanggan yang

sudah login meng-

tap navigasi Lihat

Profil di halaman

drawer navigasi

$7 \quad$ Tap Ganti Profil pada halaman profil

8 Mengganti data pelanggan dan meng-tap tombol "GANTI" di
Menunjukkan

halaman profil

$\mathrm{OK}$

Menunjukkan

$\mathrm{OK}$

halaman ganti

profil

Mengganti data

OK pelanggan di basis data, menunjukkan kalimat ganti profil 
halaman ganti profil

$9 \quad$ Tap navigasi login di halaman drawer navigasi

10 Memasukkan nomor HP dan sandi dengan benar, meng-tap tombol "LOGIN" di halaman login

11 Meng-tap tombol Daftar di halaman login

12 Meng-tap tombol "DAFTAR" dan seluruh data pelanggan dalam kondisi terisi di halaman daftar

13 Pelanggan yang sudah login mengtap tombol "BELI SEKARANG" di halaman detail produk

14 Pelanggan yang telah login mengtap ikon keranjang di halaman beranda

15 Memasukkan pesan pemesanan dan meng-tap tombol "BAYAR" di halaman keranjang belanja

16 Pelanggan yang sudah login mengtap navigasi Transaksi di halaman drawer navigasi

17 Pelanggan mengtap sebuah transaksi di halaman history transaksi

18 Pelanggan yang telah login mengtap navigasi keluar di halaman drawer navigasi

19 Admin memasukkan berhasil, menunjukkan halaman lihat profil

Menunjukkan

halaman login

Menunjukkan

halaman beranda

dengan status

login yaitu nomor

HP itu

Menunjukkan

halaman daftar

Menambahkan data pelanggan $\mathrm{ke}$ basis data, menunjukkan kalimat daftar berhasil dan menunjukkan halaman login Menambahkan produk ke keranjang dan menunjukkan dialog pesan produk sukses ditambahkan ke keranjang

Menunjukkan halaman keranjang belanja pelanggan tersebut Menambahkan transaksi baru ke basis data dan menunjukkan halaman history transaksi

Menunjukkan halaman history transaksi

Menunjukkan halaman detail transaski

Menunjukkan halaman login dan mengganti status login ke pengunjung Menunjukkan halaman admin

username dan sandi

dengan tepat di

halaman login

admin

$\mathrm{OK}$

20 Admin

memasukkan data

produk dan

$\mathrm{OK}$ menglik tombol simpan pada halaman tambah produk

21 Admin mengupdate data produk dan menglik tombol Ubah pada halaman update produk

22 Admin mengklik tombol buang di baris produk pada halaman update buang produk

23 Admin mengklik menu Lap Produk di halaman admin

24 Admin mengklik tombol tindakan verifikasi, proses, atau batalkan pada halaman verifikasi pembayaran

25 Admin mengklik тепи Keluar di halaman admin

Mengentri produk ke basis data dan menunjukkan kalimat produk sukses dientri

Meng-update data $\mathrm{OK}$ produk di basis data dan menunjukkan kalimat produk sukses di-update Membuang produk $\mathrm{OK}$ di basis data dan menunjukkan kalimat produk sukses dibuang Menunjukkan halaman laporan produk Mengganti status transaksi di basis data

$\mathrm{OK}$

OK

2) Eksperimen Recommender System halaman login admin

$\mathrm{OK}$

$\mathrm{OK}$

$\mathrm{OK}$

$\mathrm{OK}$

OK
Fase-fase eksperimen recommender system (simulasi) aplikasi yang dibangun yaitu seperti di bawah ini:

a. Misalkan ada seorang pelanggan yang baru saja melakukan registrasi di basis data Toko Menkong dimana profilnya adalah seperti Tabel 2.

$\mathrm{OK}$

Tabel 2. Profil Pelanggan Baru

\begin{tabular}{cccc}
\hline C_HP & C_NAMA & C_ALAMAT & C_HOBI \\
\hline $0821 \times x$ & Noviyana & Jebu Darat & Memasak \\
\hline
\end{tabular}

b. Noviyana login, meng-tap navigasi rekomendasi di halaman drawer navigasi. Setelah itu dilakukan pemberian nilai awal (nol) record di tabel saran untuk Noviyana seperti yang diperlihatkan Tabel 3.

Tabel 3. Inisialisasi Tabel Saran

OK

\begin{tabular}{ccccc}
\hline C_KDB & C_SKO & C_SKO & C_SKO & C_SKO \\
RG & R1 & R2 & R3 & RTOT \\
\hline 1001 & 0 & 0 & 0 & 0 \\
1002 & 0 & 0 & 0 & 0 \\
1003 & 0 & 0 & 0 & 0 \\
1004 & 0 & 0 & 0 & 0 \\
2001 & 0 & 0 & 0 & 0 \\
2002 & 0 & 0 & 0 & 0 \\
\hline
\end{tabular}




\begin{tabular}{lllll}
\hline 2003 & 0 & 0 & 0 & 0 \\
2004 & 0 & 0 & 0 & 0 \\
3001 & 0 & 0 & 0 & 0 \\
3002 & 0 & 0 & 0 & 0 \\
3003 & 0 & 0 & 0 & 0 \\
3004 & 0 & 0 & 0 & 0 \\
\hline
\end{tabular}

c. Noviyana gemar memasak, oleh karena itu C_SKOR1 seluruh produk kategori sembako (kode awalan 3) ditambah 0.2. Apabila navigasi rekomendasi diketuk, nanti akan dipilih 1 dari 4 item yang C_SKORTOT-nya paling tinggi (0.2) secara acak. Tabel saran bagi pelanggan Noviyana saat ini dapat dilihat di Tabel 4.

Tabel 4. Perhitungan Skor 1 di Tabel Saran

\begin{tabular}{ccccc}
\hline $\begin{array}{c}\text { C_KDB } \\
\text { RG }\end{array}$ & $\begin{array}{c}\text { C_SKO } \\
\text { R1 }\end{array}$ & $\begin{array}{c}\text { C_SKO } \\
\text { R2 }\end{array}$ & $\begin{array}{c}\text { C_SKO } \\
\text { R3 }\end{array}$ & $\begin{array}{c}\text { C_SKOR } \\
\text { TOT }\end{array}$ \\
\hline 1001 & 0 & 0 & 0 & 0 \\
1002 & 0 & 0 & 0 & 0 \\
1003 & 0 & 0 & 0 & 0 \\
1004 & 0 & 0 & 0 & 0 \\
2001 & 0 & 0 & 0 & 0 \\
2002 & 0 & 0 & 0 & 0 \\
2003 & 0 & 0 & 0 & 0 \\
2004 & 0 & 0 & 0 & 0 \\
3001 & 0.2 & 0 & 0 & 0.2 \\
3002 & 0.2 & 0 & 0 & 0.2 \\
3003 & 0.2 & 0 & 0 & 0.2 \\
3004 & 0.2 & 0 & 0 & 0.2 \\
\hline
\end{tabular}

d. Noviyana menambahkan ke keranjang Bango kecap manis botol $135 \mathrm{ml}$ (kode produk 3002). Sistem mengkalkulasikan banyaknya produk di keranjang menurut kategori (tidak mempertimbangkan kuantitas). C_SKORTOT produk yang sudah ada di keranjang dibuat 0 (agar tidak menyarankan produk yang sudah ada di keranjang). Apabila navigasi rekomendasi diketuk, sistem akan menyarankan sembako selain 3002. Tabel saran bagi Noviyana saat ini dapat dilihat di Tabel 5.

Tabel 5. Perhitungan Skor 2 di Tabel Saran

\begin{tabular}{|c|c|c|c|c|}
\hline $\begin{array}{c}\text { C_KDB } \\
\text { RG }\end{array}$ & $\begin{array}{c}\text { C_SKO } \\
\text { R1 }\end{array}$ & $\begin{array}{c}\text { C_SKO } \\
\text { R2 }\end{array}$ & $\begin{array}{c}\text { C_SKO } \\
\text { R3 }\end{array}$ & $\begin{array}{l}\text { C_SKO } \\
\text { RTOT }\end{array}$ \\
\hline 1001 & 0 & 0 & 0 & 0 \\
\hline 1002 & 0 & 0 & 0 & 0 \\
\hline 1003 & 0 & 0 & 0 & 0 \\
\hline 1004 & 0 & 0 & 0 & 0 \\
\hline 2001 & 0 & 0 & 0 & 0 \\
\hline 2002 & 0 & 0 & 0 & 0 \\
\hline 2003 & 0 & 0 & 0 & 0 \\
\hline 2004 & 0 & 0 & 0 & 0 \\
\hline 3001 & 0.2 & 0.3 & 0 & 0.5 \\
\hline 3002 & 0.2 & 0.3 & 0 & 0 \\
\hline 3003 & 0.2 & 0.3 & 0 & 0.5 \\
\hline 3004 & 0.2 & 0.3 & 0 & 0.5 \\
\hline
\end{tabular}

e. Noviyana menambahkan minyak goreng Fortune $1 \mathrm{~L}$ (3001), setelah itu menambahkan Cheetos jagung bakar 15 gr (1001) ke keranjang. Jumlah makanan ringan (kode awalan 1) di keranjang saat ini 1 buah, sehingga C_SKOR3 seluruh produk minuman (kode awalan 2) ditambah 0.5 dengan asumsi pelanggan pada umumnya juga akan membeli minuman ketika membeli makanan ringan. Apabila rekomendasi ditap, sistem nantinya memperlihatkan satu dari 4 minuman pada basis data. C_SKOR2 sekarang menurun dari 0.3 menjadi 0.2 karena sudah ada 2 jenis produk berkategori sembako di keranjang. Tabel saran bagi Noviyana saat ini diperlihatkan di Tabel 6.

Tabel 6. Perhitungan Skor 2 dan Skor 3 di Tabel Saran

\begin{tabular}{ccccc}
\hline C_KDB & C_SKO & C_SKO & C_SKO & $\begin{array}{c}\text { C_SKO } \\
\text { RG }\end{array}$ \\
\hline R1 & R2 & R3 & RTOT \\
\hline 1001 & 0 & 0.3 & 0 & 0 \\
1002 & 0 & 0.3 & 0 & 0 \\
1003 & 0 & 0.3 & 0 & 0.3 \\
1004 & 0 & 0.3 & 0 & 0.3 \\
2001 & 0 & 0 & 0.5 & 0.5 \\
2002 & 0 & 0 & 0.5 & 0.5 \\
2003 & 0 & 0 & 0.5 & 0.5 \\
2004 & 0 & 0 & 0.5 & 0.5 \\
3001 & 0.2 & 0.2 & 0 & 0 \\
3002 & 0.2 & 0.2 & 0 & 0 \\
3003 & 0.2 & 0.2 & 0 & 0.4 \\
3004 & 0.2 & 0.2 & 0 & 0.4 \\
\hline
\end{tabular}

Aplikasi yang sudah dibangun setelah itu dicoba oleh 15 orang responden yang dimana hasilnya dapat dilihat di Tabel 7, dimana pertanyaan-pertanyaan pada kuesioner yaitu seperti di bawah ini:

a. Aplikasi bisa dijalankan secara mudah.

b. Pengalaman ketika menggunakan aplikasi ini sama seperti menggunakan aplikasi $m$-commerce sejenis seperti Tokopedia, Bukalapak, dan Shopee.

c. Waktu yang dibutuhkan dalam membeli produk di Toko Menkong menjadi lebih sedikit dengan menggunakan aplikasi ini.

d. Proses pemesanan produk di Toko Menkong menjadi lebih mudah dengan menggunakan aplikasi ini.

e. Produk yang disarankan pada aplikasi cocok dengan keperluan Anda.

Tabel 7. Hasil Rekapitulasi Kuesioner

\begin{tabular}{clccccc}
\hline \multirow{2}{*}{ No } & \multicolumn{1}{c}{ Nama } & \multicolumn{5}{c}{ Soal } \\
& & $\mathbf{2}$ & $\mathbf{3}$ & $\mathbf{4}$ & $\mathbf{5}$ \\
\hline 1 & Noviyana & SS & S & SS & S & S \\
2 & Cindy Lawrenza & S & CS & S & CS & SS \\
3 & Yuliana & S & SS & SS & S & KS \\
4 & Aseng & SS & S & S & S & S \\
5 & Siti Masito & S & SS & S & CS & CS \\
6 & Burhanudin & CS & KS & CS & KS & KS \\
7 & Lia Risnawati & S & S & S & S & S \\
8 & Rita Berlian & KS & CS & S & SS & KS \\
9 & Zulkarnain & S & S & SS & S & S \\
10 & Fatimah & SS & S & CS & CS & SS \\
11 & Felisia & S & CS & SS & S & S \\
12 & Tina & CS & KS & S & SS & CS \\
\hline
\end{tabular}




\begin{tabular}{llccccc}
\hline 13 & Rian Rendi & S & S & CS & S & S \\
14 & Rizki Purwanto & SS & CS & S & SS & KS \\
15 & Tomi Ali & S & S & S & S & SS \\
\hline KS $=$ Kurang Setuju, CS $=$ Cukup Setuju, S $=$ Setuju & SS $=$ Sangat Setuju
\end{tabular}

Sebanyak 73,33\% atau 11 dari 15 responden menurut persamaan (5) dan Tabel 7 setuju (selain kurang setuju/ KS) bahwa produk yang disarankan aplikasi cocok dengan keperluan mereka di waktu itu.

$$
\begin{gathered}
=\frac{\begin{array}{c}
\% \text { Akurasi } \\
\text { Banyaknya Responden Setuju }
\end{array}}{\text { Banyaknya Responden }} \\
\times 100 \%=\frac{11}{15} \times 100 \%=73,33 \%
\end{gathered}
$$

\section{Kesimpulan}

Berbagai kesimpulan yang bisa ditarik berdasarkan beberapa paparan yang sudah dijelaskan pada paper ini yaitu sebagai berikut:

a. Proses pemesanan produk di Toko Menkong oleh pelanggan menjadi lebih cepat, mudah, dan efisien berkat aplikasi yang dibangun.

b. Pelanggan yang bisa dijangkau oleh Toko Menkong menjadi lebih banyak dan dalam kawasan yang lebih luas, akibatnya jumlah transaksi yang terjadi per hari semakin banyak dan omset meningkat.

c. Akurasi recommender system dari aplikasi yang dibangun cukup baik dalam menyarankan produk menurut hobi pelanggan, kategori produk di keranjang, dan skema belanja pelanggan pada umumnya, yakni sebesar 73,33\%

\section{Daftar Pustaka}

[1] J.H. Mustakini, Sistem Teknologi Informasi: Pendekatan Terintegrasi: Konsep Dasar, Teknologi, Aplikasi, Pengembangan, dan Pengelolaan, 3rd ed., Andi, Yogyakarta, 2009.

[2] T. Arifianto, Membuat Interface Aplikasi Android Lebih Keren dengan LWUIT, Andi Publisher, Yogyakarta, 2011.

[3] Hartanto, "Analisis Pengendalian Internal Pengelolaan Pembelian Impor pada PT. XYZ", Skripsi, Fakultas Ekonomi, Universitas Esa Unggul, Jakarta, 2011.

[4] N.S. Harahap, Pemrograman Aplikasi Mobile Smartphone dan Tablet PC Berbasis Android, Informatika, Bandung, 2012.

[5] T. Badriyah, R. Fernando, \& I. Syarif, "Sistem Rekomendasi Content Based Filtering Menggunakan Algoritma Apriori", In Konferensi Nasional Sistem Informasi (KNSI) 2018, pp. 554-559, 2018.

[6] H. Susanto, "Perancangan Sistem Rekomendasi Pakaian Distro dengan Menggunakan Item
Collaborative Filtering (Studi Kasus : The Jungle Distro Medan)", Pelita Informatika Budi Darma, vol. 6, no. 3, pp. 58-62, 2014.

[7] Y.I. Santoso, \& D.P. Kusumaningrum, Penerapan Metode Content Based Filtering untuk Sistem Rekomendasi Jual Beli Online. http://mahasiswa.dinus.ac.id/docs/skripsi/jurnal/186 99.pdf, 2016, retrieved April 10, 2018

[8] M.K. Sarkaleh, M. Mahdavi, \& M. Baniardalan, "Designing a Tourism Recommender System based on Location, Mobile Device and User Features in Museum", International Journal of Managing Information Technology (IJMIT), vol. 4, no. 2, pp. 1321,2012

[9] N. Yanti, R. Rahmi, \& R. Ruliah, "Penerapan Algoritma Collaborative Filtering untuk Rekomendasi Games Hardware", Jurnal Teknik Informatika dan Sistem Informasi (JUTISI), vol. 2, no. 1, pp. 305-314, 2013.

[10] T. Badriyah, E.T. Wijayanto, I. Syarif, \& P. Kristalina, "A Hybrid Recommendation System for ECommerce based on Product Description and User Profile", In The Seventh International Conference on Innovative Computing Technology (INTECH 2017), pp. 95-100, 2017.

[11] V. Armando, "Sistem Rekomendasi Pembelian Telepon Genggam dengan Metode Content-based Filtering”, Skripsi, Fakultas Teknologi Industri, Universitas Atma Jaya. Yogyakarta, 2017.

[12] R. McLeod Jr., Sistem Informasi Manajemen, Vol. 2, 7 th ed., diterjemahkan oleh H. Teguh, Prenhallindo, Jakarta, 2001.

[13] F. Jiang, \& Y. Lu, "Software Testing Model Selection Research Based on Yin-Yang Testing Theory", In 2012 International Conference on Computer Science and Information Processing (CSIP), pp. 590-594, 2012.

[14] A. Nugroho, Analisis dan Pemrograman Berorientasi Objek, 2nd ed., Informatika, Bandung, 2004.

[15]A. Nugroho, Analisis dan Perancangan Sistem Informasi dengan Metodologi Berorientasi Objek, Informatika, Bandung, 2005.

[16] J. Han, M. Kamber, \& J. Pei, Data Mining: Concepts and Techniques, 3rd ed., Morgan Kaufmann, Waltham, 2012.

[17] Kusrini, \& E.T. Luthfi, Algoritma Data Mining, Penerbit ANDI, Yogyakarta, 2009.

[18] A. Haris, Data Mining _ Definisi dan cara kerja Algoritma Apriori untuk pencarian association rule, https://medium.com/@infharis/data-mining-definisidan-cara-kerja-algoritma-apriori-untuk-pencarianassociation-rule-a44a8f864a61，2016, retrieved January 14 Januari, 2019.

[19] P.S. Adi, "Sistem Rekomendasi Nilai Mata Kuliah Menggunakan Metode Content-Based Filtering", In Seminar Nasional Informatika 2010 (semnasIF 2010), pp. A-90-A94, 2010. 